\title{
Regulation of energy metabolism in pancreatic islets by glucose and tolbutamide
}

\author{
U.Panten, B.J.Zünkler, S. Scheit, K. Kirchhoff and S. Lenzen \\ Institute of Pharmacology and Toxicology, University of Göttingen, Göttingen, FRG
}

\begin{abstract}
Summary. The kinetics of insulin secretion and oxygen uptake in response to D-glucose and tolbutamide were compared in mouse pancreatic islets. In addition, the role of decreased ATP as a driving force for secretagogue-induced oxygen consumption was examined. D-glucose ( $10-30 \mathrm{mmol} / 1)$ triggered a biphasic insulin release which always coincided with a monophasic increase in islet oxygen uptake. In the presence of Dglucose $(5-30 \mathrm{mmol} / \mathrm{l})$, tolbutamide $(3-500 \mu \mathrm{mol} / \mathrm{l})$ consistently elicited an initial peak of insulin secretion which was followed by a continued decline. Tolbutamide-induced secretory profiles were accompanied by similar respiratory profiles. Oxygen consumption per ng of insulin released during the test phase was higher after elevation of the glucose concentration than after addition of tolbutamide. In conjunction
\end{abstract}

with 5 or $10 \mathrm{mmol} / 1 \mathrm{D}$-glucose, but not with 15 or $30 \mathrm{mmol} / 1$ D-glucose, tolbutamide $(30-100 \mu \mathrm{mol} / \mathrm{l})$ lowered islet ATP content significantly $(p<0.02)$. Phosphocreatine was not found in isolated islets, although they contained substantial creatine kinase activity. It is concluded that the driving force for tolbutamide-induced oxygen uptake is a decrease in the phosphorylation potential caused by the work load imposed by stimulation of the secretion process. However, a major proportion of the respiratory response to glucose also results from enhancement of biosynthesis.

Key words: Islets of Langerhans, insulin secretion, $\mathrm{O}_{2}$ uptake, ATP, creatine kinase, D-glucose, tolbutamide.

These drugs neither stimulate catabolic processes nor cause an increase in the content of reduced pyridine nucleotides [NAD $(\mathrm{P}) \mathrm{H}]$ in pancreatic islets [12-14]. Hence, the stimulation of ATP consumption in the B cells due to the work load imposed by the secretory response to sulfonylureas is expected to lower the cytosolic ATP concentration, thereby antagonizing partly the $\beta$-cytotropic effects of nutrient secretagogues. The kinetic of sulfonylurea-induced insulin release which declines after an initial maximum perhaps reflects such an interaction $[15,16]$. However, the dependence of this kinetic upon the concentrations of sulfonylureas and nutrients is not established in isolated islets. Furthermore, it is unclear whether the sulfonylurea-induced work load is strong enough to modulate insulin secretion. Firstly, tolbutamide and glibenclamide caused both stimulation and inhibition of islet oxygen $\left(\mathrm{O}_{2}\right)$ uptake in experiments requiring long incubation periods $[17,18]$. Secondly, conflicting results have been published concerning the effects of sulfonylureas on islet content of ATP. No change, an increase or a decrease were reported and experimental conditions were used which may produce effects not related to insulin release $[8,12$,

18-20]. Thus, it is not possible to decide whether the re- plasma membrane [10], probably by direct inhibition of the same $\mathrm{K}^{+}$channel which is the target for ATP [11]. requires the proof that in $B$ cells the total ATP content is not representative of the ATP concentration in the vicinity of the $\mathrm{K}^{+}$channel.

Sulfonylureas (e.g. tolbutamide) trigger insulin release by acting upon specific receptors in the B-cell 
ported decrease in ATP content of islets reflects the energy requirements of the secretion process [21].

We have therefore undertaken a detailed comparison of the effects of D-glucose and tolbutamide on insulin secretion and islet energy metabolism in order to elucidate further the role of ATP in the function of the pancreatic B cell.

\section{Materials and methods}

\section{Chemicals and media}

The following substances were used: 3,5-diaminobenzoic acid hydrochloride from Fluka, Buchs, Switzerland; crystalline rat insulin from Novo, Bagsvaerd, Denmark; ${ }^{125}$ I-labelled porcine insulin from Behringwerke, Frankfurt, FRG; bovine serum albumin (fraction V) from Miles, Frankfurt, FRG; imidazole (fluorimetric grade), dithiothreitol, P-creatine, $\mathrm{p}^{1}, \mathrm{p}^{5}$-di(adenosine $\left.5^{5}\right)$ pentaphosphate $\left(\mathrm{Ap}_{5} \mathrm{~A}\right.$, lithium salt), calf thymus DNA (type I), charcoal (hydrochloric acid washed) and glucose-6-phosphate dehydrogenase (EC 1.1.1.49; from Leuconostoc mesenteroides) from Sigma, St. Louis, Mo, USA; collagenase (type IV) from Worthington, Freehold, NJ, USA. All other enzymes, the nucleotides, D-luciferin, glutathion, Tris and triethanolamine were purchased from Boehringer, Mannheim, FRG. Tolbutamide was a gift from Hoechst AG, Frankfurt, FRG. D-Glucose and all other reagents were analytical grade from Merck, Darmstadt, FRG.

Basal medium for isolation, incubation and perifusion of pancreatic islets was prepared as previously described [22] except that for measurement of $\mathrm{O}_{2}$ consumption it was equilibrated with $\mathrm{O}_{2} / \mathrm{N}_{2} / \mathrm{CO}_{2}$ $(12: 7: 1)$. As indicated in the Results section, in some experiments calcium was omitted from all media and $1 \mathrm{mmol} / 1$ ethylene glycol bis $(\beta$ aminoethyl ether)-N,N,N',N'-tetracetic acid (EGTA; $\mathrm{NaOH}$ to give $\mathrm{pH} 7.4)$ was added. Stock solutions $(20 \mathrm{mmol} / \mathrm{l})$ of tolbutamide were prepared daily by dissolving tolbutamide in $\mathrm{NaOH}(50 \mathrm{mmol} / \mathrm{l})$ and adjusting the $\mathrm{pH}$ to 8.5 with $\mathrm{HCl}$.

\section{Isolation of pancreatic islets}

Pancreatic islets were isolated from male albino mice (NMRI, 11-15 weeks old, fed ad libitum) by collagenase digestion [23] in basal medium supplemented with glucose $(5 \mathrm{mmol} / \mathrm{l})$.

\section{Measurement of insulin secretion}

Batches of 50 islets were perifused at $0.9 \mathrm{ml} / \mathrm{min}$ at $37^{\circ} \mathrm{C}$ as detailed previously [24]. At zero time (after perifusion for $44 \mathrm{~min}$ with control medium containing $0,5,10,15$ or $30 \mathrm{mmol} / 1$ glucose) the distribution valve of the system was switched to control or test medium. No correction for the dead space between valve and islets (about $0.4 \mathrm{ml}$ ) was made. Insulin content of 1-4 min fractions was determined by radioimmunosassay with rat insulin as reference [25].

\section{Measurement of $\mathrm{O}_{2}$ consumption}

$\mathrm{O}_{2}$ consumption by batches of $90-150$ islets was recorded at $37^{\circ} \mathrm{C}$ as described previously [26], except that the response time of the measuring system was $15-30$ s for $99 \%$ change. After incubation for $45 \mathrm{~min}$ with control medium $(0,5,10,15$ or $30 \mathrm{mmol} / \mathrm{l} \mathrm{D}$-glucose $)$ the same medium with or without test substance (to give the final glucose or tolbutamide concentrations in the incubation chamber) was injected into the chamber (zero time). $\mathrm{O}_{2}$ consumption by the islets was calculated from the decrease in the $\mathrm{pO}_{2}$ during 1-4 min intervals and from the amount of medium in the closed incubation chamber, with corrections for atmospheric pressure, water vapour and drift, and with Bunsen's solubility coefficient of $0.0227 \mathrm{ml} / \mathrm{ml}$ (at $37^{\circ} \mathrm{C}$ ). The DNA content of the islets was measured as described [26]. In control experiments insulin secretion was measured by removing $10 \mu \mathrm{l}$ aliquots from the medium. In the presence of 10 or $15 \mathrm{mmol} / 1 \mathrm{D}$-glucose, tolbutamide $(100 \mu \mathrm{mol} / \mathrm{l})$ enhanced insulin secretion with an initial overshoot coinciding with the $\mathrm{O}_{2}$ uptake peaks in separate experiments (Fig. 5).

\section{Measurement of ATP and P-creatine content}

Batches of 30 islets were preincubated $(45 \mathrm{~min})$ and incubated $(15 \mathrm{~min})$ at $37^{\circ} \mathrm{C}$ in $100 \mu \mathrm{l}$ of medium as described previously [22]. After preincubation, $90 \mu 1$ of medium were removed and replaced by $90 \mu \mathrm{l}$ of control or test medium. Incubations were stopped by removing rapidly $90 \mu \mathrm{l}$ of medium, pipetting $90 \mu \mathrm{l}$ of ice-chilled $\mathrm{NaOH}$ $(0.1 \mathrm{~mol} / \mathrm{l})$ supplemented with EDTA $(2 \mathrm{mmol} / \mathrm{l})$ into the incubation tube, sonicating the stoppered tube in an ice bath by pressing it for $1 \mathrm{~min}$ against the $12 \mathrm{~mm}$ tip of a sonifier (Branson type B15P, pulsed mode with $40 \%$ duty cycle) and heating the tube for $10 \mathrm{~min}$ at $60^{\circ} \mathrm{C}$. After neutralization with $45 \mu \mathrm{l}$ of Hepes $(0.4 \mathrm{~mol} / \mathrm{l})$ supplemented with EDTA $(2 \mathrm{mmol} / \mathrm{l})$ and $\mathrm{Ap}_{5} \mathrm{~A}(20 \mu \mathrm{mol} / \mathrm{l})$, ATP and P-creatine were measured according to Lust et al. [27] with minor modifications. Forty $\mu$ l-aliquots were mixed with $20 \mu \mathrm{l}$ of reaction mixture $\left(50 \mathrm{mmol} / 1 \mathrm{imidazole} / \mathrm{HCl}, \mathrm{pH} 7.0,15 \mathrm{mmol} / 1 \mathrm{MgCl}_{2}, 0.2 \mathrm{mg} / \mathrm{ml}\right.$ albumin, $0.2 \mathrm{mmol} / 1 \mathrm{ADP}, 24 \mathrm{U} / \mathrm{ml}$ creatine kinase) or of the same mixture without ADP and creatine kinase. After 30 min at room temperature, $25 \mu \mathrm{l}$-aliquots were mixed with $100 \mu \mathrm{l}$ of luciferase reagent ( $56 \mathrm{mmol} / 1$ Tris/acetate, $\mathrm{pH} 7.7,1.5 \mathrm{mmol} / 1$ EDTA, $6 \mathrm{mmol} / 1 \mathrm{di}-$ thiothreitol, $20 \mathrm{mmol} / 1$ magnesium acetate, $0.8 \mathrm{mg} / \mathrm{ml}$ albumin, $70 \mu \mathrm{mol} / 1$ luciferin, $0.6 \mu \mathrm{g} / \mathrm{ml}$-firefly luciferase) and the luminescence was monitored with a Biocounter M2010 (Lumac, Meise, Belgium). Blanks, ATP standards and P-creatine standards were prepared with medium and run through the entire procedure together with samples. The DNA content of the islets was measured in $40 \mu$-aliquots of the neutralized samples using DNA standards in adequate volumes of mixtures of the different media with the neutralized quenching solution [26].

\section{Measurement of creatine kinase}

Pancreatic islets, total pancreas or brain from albino mice were homogenized in $10 \mathrm{mmol} / 1 \mathrm{Tris} / \mathrm{HCl}, \mathrm{pH} 7.0$ at $0^{\circ} \mathrm{C}$ immediately after isolation. $10 \mu \mathrm{l}$ of the homogenate (corresponding to $1-10 \mu \mathrm{g}$ of tissue protein) were added to $1 \mathrm{ml}$ of reaction mixture $(100 \mathrm{mmol} / 1$ triethanolamine $/ \mathrm{HCl}, \mathrm{pH} 7.0,10 \mathrm{mmol} / 1 \mathrm{MgCl}_{2}, 20 \mathrm{mmol} / 1 \mathrm{D}$-glucose, $10 \mathrm{mmol} / 1$ glutathion, $1 \mathrm{mmol} / 1 \mathrm{ADP}, 10 \mathrm{mmol} / 1 \mathrm{AMP}, 0.5 \mathrm{mmol} / 1$ $\mathrm{NAD}^{+}, 0.5 \mathrm{U} / \mathrm{ml}$ glucose 6 -phosphate dehydrogenase, $0.5 \mathrm{U} / \mathrm{ml}$ hexokinase). After $5 \mathrm{~min}$ at $37^{\circ} \mathrm{C}$ in the photometer, the reaction was started with $100 \mu \mathrm{l}$ of P-creatine $(350 \mathrm{mmol} / \mathrm{l})$ and extinction at $340 \mathrm{~nm}$ was recorded after the lag phase. Recordings without P-creatine were used as parallel blanks. The protein content of the homogenates was determined as described [28].

\section{Statistical analysis}

Results are presented as mean \pm SEM for independent experiments. Significances were calculated by the two-tailed matched-pairs signed rank test of Wilcoxon or by the two-tailed U-test of Wilcoxon and of Mann and Whitney. $p<0.05$ was considered significant. Increase in insulin release or $\mathrm{O}_{2}$ uptake was calculated by subtracting the last value before zero time. For calculation of the ratio of the increase in $\mathrm{O}_{2}$ uptake to the increase in insulin release, the increase in $\mathrm{O}_{2}$ uptake of tests was corrected by subtracting the corresponding increase of controls.

\section{Results}

In mouse islets perifused for 44 min with 5,10 or $15 \mathrm{mmol} / 1 \mathrm{D}$-glucose, elevation of the medium glucose concentration to 10,15 or $30 \mathrm{mmol} / \mathrm{l}$, respectively, 


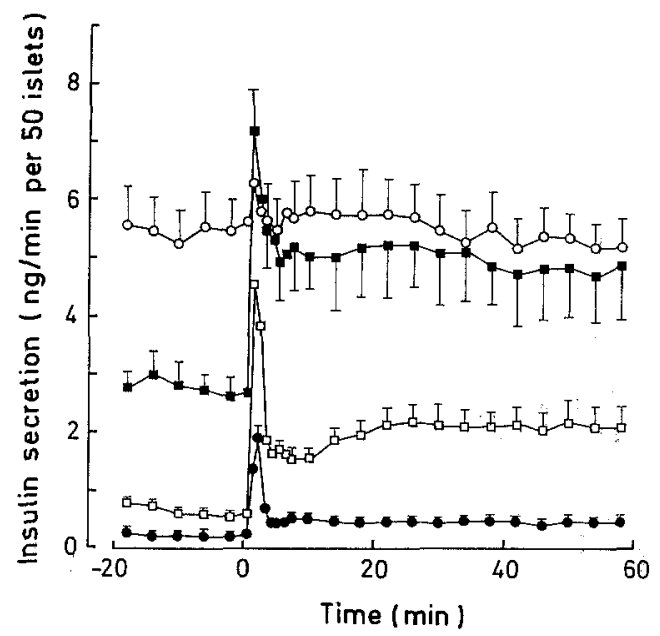

Fig. 1. Effects of glucose concentration on the kinetic of insulin secretion by mouse pancreatic islets. At zero time the D-glucose concentration of the perifusion medium was changed from 5 to $10 \mathrm{mmol} / 1(\bullet)$, from 10 to $15 \mathrm{mmol} / 1$ (口), from 15 to $30 \mathrm{mmol} / \mathrm{l}$ ( $\mathbf{\square}$ ) or from 30 to $40 \mathrm{mmol} / 1(\mathrm{O})$. Values in the curves are means $\pm \mathrm{SEM}$ of results from 6 separate experiments and are drawn in the middle of the sampling intervals. For the sake of clarity SEM of some means are not shown. In each separate experiment of the series elevation of the glucose concentration to 10,15 or $30 \mathrm{mmol} / 1$ enhanced insulin secretion from $1.5 \mathrm{~min}$ to $58 \mathrm{~min}$ as compared to the rate at $-2 \mathrm{~min}$

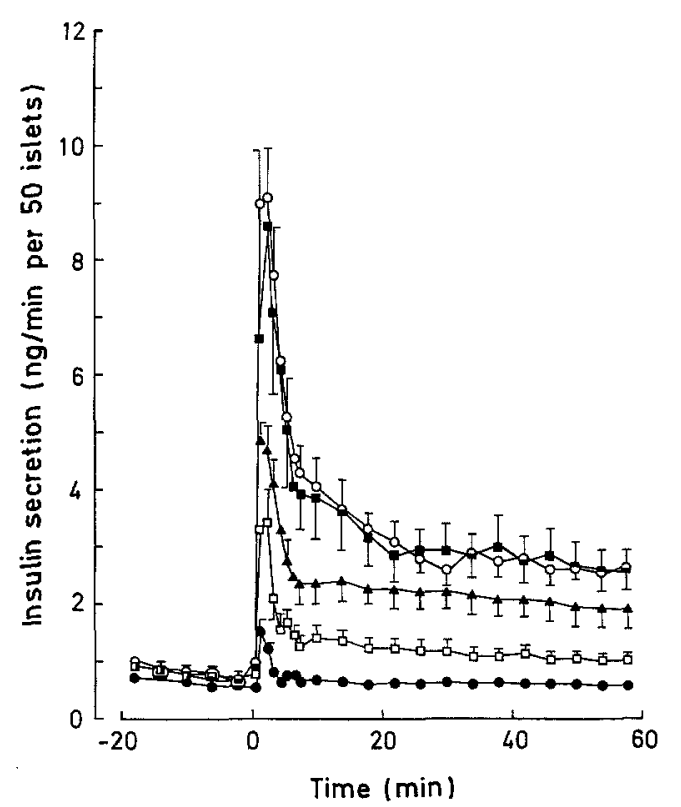

Fig. 2. Effects of tolbutamide concentration on the kinetic of insulin secretion by mouse pancreatic islets. All control and test media contained $10 \mathrm{mmol} / 1 \mathrm{D}$-glucose. From zero time to $60 \mathrm{~min}$ the perifusion medium contained $3 \mu \mathrm{mol}$ (๑), $10 \mu \mathrm{mol} / 1$ (ㅁ), $30 \mu \mathrm{mol} / 1$ (A), $100 \mu \mathrm{mol} / 1(\mathbb{Q})$ or $500 \mu \mathrm{mol} / 1(\mathrm{O})$ tolbutamide. Values in the curves are means \pm SEM of results from 6 separate experiments. In each separate experiment of the series $3 \mu \mathrm{mol} / 1$ or 10 to $500 \mu \mathrm{mol} / 1$ tolbutamide enhanced insulin secretion from $1.5 \mathrm{~min}$ to 6.5 or $58 \mathrm{~min}$, respectively, as compared to the rate at $-2 \mathrm{~min}$. For further details see Figure 2

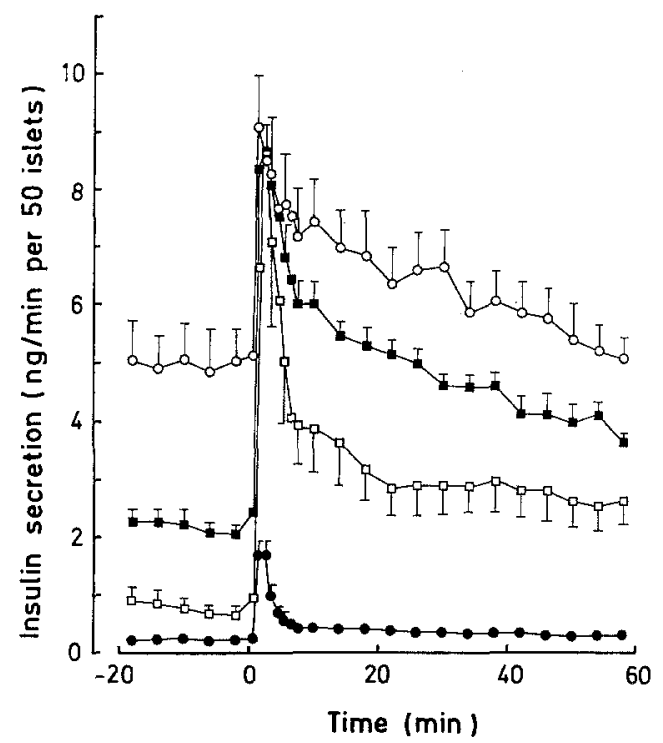

Fig. 3. Effects of glucose concentration on the kinetic of tolbutamideinduced insulin secretion by mouse pancreatic islets. Control and test medium contained $5 \mathrm{mmol} / 1(\bullet), 10 \mathrm{mmol} / 1(\square), 15 \mathrm{mmol} / 1$ ( $\mathbf{\square}$ ) or $30 \mathrm{mmol} / \mathrm{l}(\mathrm{O}) \mathrm{D}$-glucose. From zero time to $60 \mathrm{~min}$ all perifusion media contained $100 \mu \mathrm{mol} / 1$ tolbutamide. Values in the curves are means \pm SEM of results from 6 separate experiments. In each separate experiment of the series tolbutamide enhanced insulin secretion in the presence of $5,10,15$ or $30 \mathrm{mmol} / 1 \mathrm{D}$-glucose from $1.5 \mathrm{~min}$ to 30 , 58,58 or $30 \mathrm{~min}$, respectively, as compared to the rate at $-2 \mathrm{~min}$. Further details are the same as described in the legend to Figure 1

caused an increase in insulin release which was maximal at $1.5-2.5 \mathrm{~min}$ in each single experiment and reached a new steady state not later than at $24 \mathrm{~min}$ (Fig.1). Transition from 30 to $40 \mathrm{mmol} / \mathrm{l} \mathrm{D}$-glucose did not change insulin secretion significantly, indicating that $30 \mathrm{mmol} / 1$ was already maximally effective (Fig. 1). Control studies demonstrated that during perifusion without change of glucose concentration at zero time, insulin secretion did not increase in the presence of 5 , 10 or $15 \mathrm{mmol} / 1 \mathrm{D}$-glucose from zero time up to $58 \mathrm{~min}$ (results not shown).

When islets were perifused with a slightly effective glucose concentration $(10 \mathrm{mmol} / \mathrm{l})$, tolbutamide $(3,10$, $30,100$ or $500 \mu \mathrm{mol} / 1)$ stimulated a steep increase in insulin release (Fig. 2) culminating at 1.5-3.5 min and falling to less than $60 \%$ of the peak rate at $10 \mathrm{~min}$ in each single experiment. Subsequently insulin secretion decreased more slowly, but at all tolbutamide concentrations the secretory rate at $58 \mathrm{~min}$ was significantly $(p<$ 0.05 ) lower than that at $10 \mathrm{~min}$. The half maximally effective concentration of tolbutamide ranged between $10 \mu \mathrm{mol} / 1$ and $30 \mu \mathrm{mol} / 1$ (Fig. 2). In each single experiment testing the effect of glucose concentration $(5,10$, 15 or $30 \mathrm{mmol} / \mathrm{l}$ ) upon insulin release elicited by $100 \mu \mathrm{mol} / 1$ tolbutamide, rate of insulin secretion at $10 \mathrm{~min}$ was lower than that at $1.5-2.5 \mathrm{~min}$ and higher than that at $58 \mathrm{~min}$ (Fig.3). In the absence of glucose, 


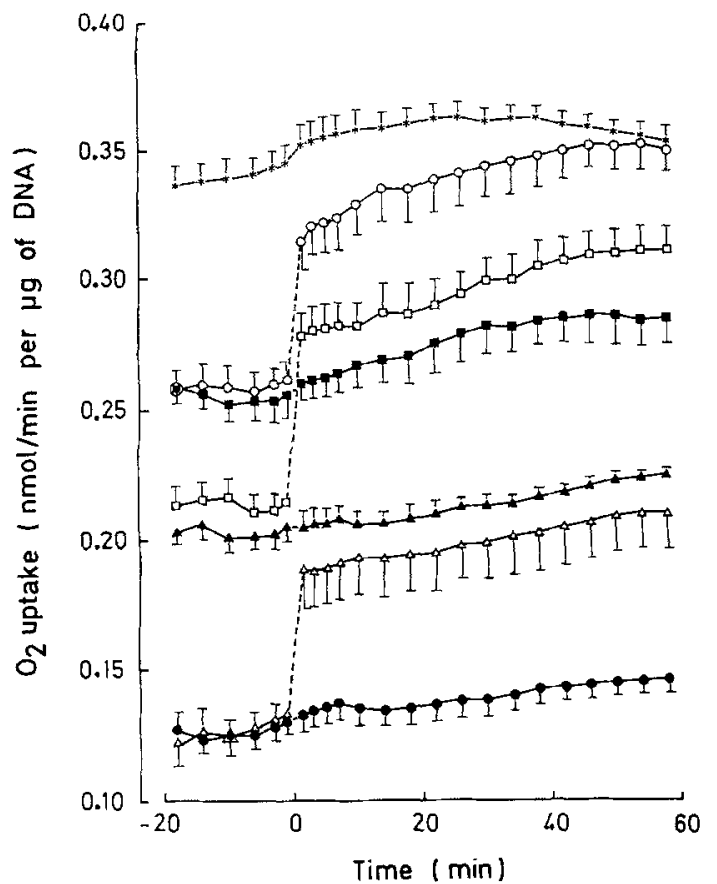

Fig.4. Effects of glucose concentration on the kinetic of $\mathrm{O}_{2}$ uptake by mouse pancreatic islets. At zero time the D-glucose concentration of the incubation medium was changed from 5 to $10 \mathrm{mmol} / \mathrm{l}(\Delta)$, from 10 to $15 \mathrm{mmol} / \mathrm{l}(\square)$ or from 15 to $30 \mathrm{mmol} / \mathrm{l}(O)$ or the glucose concentration of the incubation medium was kept constant by injection of control medium $(5 \mathrm{mmol} / \mathrm{l},-; 10 \mathrm{mmol} / 1, \mathbf{\Lambda} ; 15 \mathrm{mmol} / 1, \mathbf{\square}$; $30 \mathrm{mmol} / \mathrm{l}, *$ ). Values in the curves are means $\pm S E M$ of results from 6 to 9 separate experiments and are drawn in the middle of the sampling intervals. For the sake of clarity SEM of some means are not shown. The mean respiratory rate between $1.5 \mathrm{~min}$ and $58 \mathrm{~min}$ in profiles $\Delta, \square$ or $\bigcirc$ was significantly higher $(p<0.02$, U-test) than this rate in the corresponding control profiles $\boldsymbol{\Delta}, \boldsymbol{\Delta}$ or $\mathbf{E}$. The broken lines in the $\mathrm{O}_{2}$ uptake profiles span the interval during which $\mathrm{O}_{2}$ uptake could not be determined because injections caused $\mathrm{pO}_{2}$ jumps

$100 \mu \mathrm{mol} / 1$ tolbutamide was ineffective and $500 \mu \mathrm{mol} / 1$ tolbutamide caused merely an initial peak of insulin release (peak rate amounting to $0.90 \pm 0.12 \mathrm{ng} \cdot \mathrm{min}^{-1}$ per 50 islets, $n=6$, secretory profile not shown). In the absence of extracellular $\mathrm{Ca}^{2+}$ ions, there was no secretory response to $100 \mu \mathrm{mol} / 1$ tolbutamide (in the presence of $10 \mathrm{mmol} / 1 \mathrm{D}$-glucose, $n=6$, results not shown).

Changing the medium glucose concentration from 5 to $10 \mathrm{mmol} / 1$, from 10 to $15 \mathrm{mmol} / 1$ or from 15 to $30 \mathrm{mmol} / \mathrm{l}$ enhanced islet $\mathrm{O}_{2}$ consumption by 42,30 or $20 \%$, respectively, within 2 min (in series $\Delta, \square$ and $O$, $p<0.05$ for comparison with the last value before zero time, Fig. 4). Then the respiratory rate increased gradually and an initial overshoot was never observed. In control experiments the rate of $\mathrm{O}_{2}$ uptake rose slowly up to $58 \mathrm{~min}$ (except in profile *). In each single experiment of the series $\bullet, \Delta, \Delta, \square, \boldsymbol{\square}$ and $\mathrm{O}$ (Fig. 4), $\mathrm{O}_{2}$ consumption at $10 \mathrm{~min}$ was lower than at $58 \mathrm{~min}$. From $5 \mathrm{~min}$ up to $58 \mathrm{~min}$ the ratio of the increase in $\mathrm{O}_{2}$ uptake to the increase in insulin release ranged above 170,44 or $20 \mathrm{pmol}$ of $\mathrm{O}_{2} / \mathrm{ng}$ of insulin after transition from 5 to $10 \mathrm{mmol} / 1$, from 10 to $15 \mathrm{mmol} / 1$ or from 15 to $30 \mathrm{mmol} / 1$ glucose respectively. The ratios were calcu-

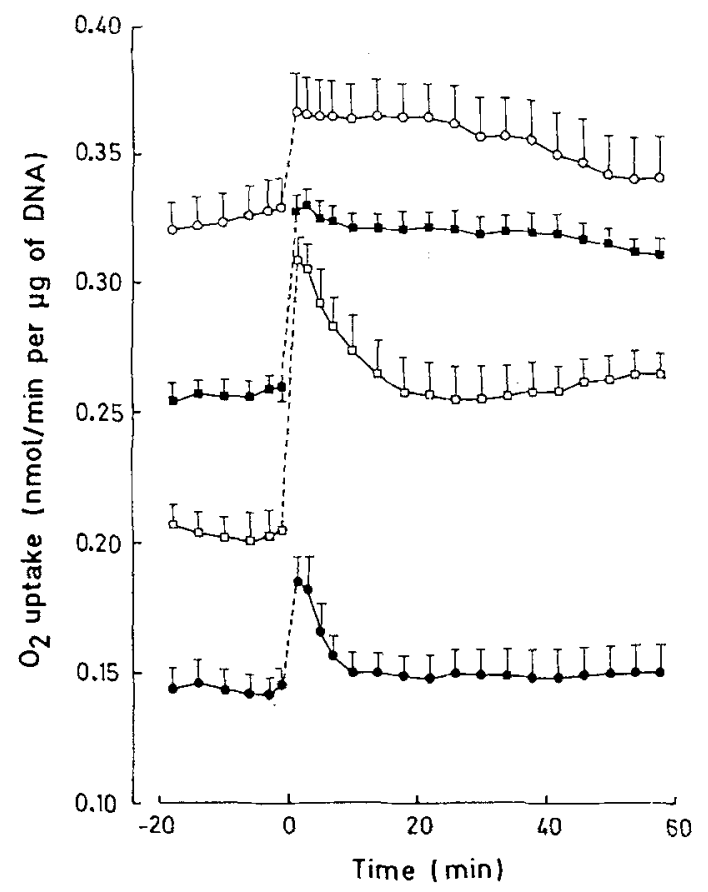

Fig.5. Effects of glucose concentration on the kinetic of tolbutamideinduced $\mathrm{O}_{2}$ uptake by mouse pancreatic islets. During control $(-20$ to $0 \mathrm{~min}$ ) and test phase the D-glucose concentration of the incubation

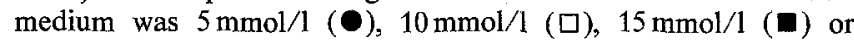
$30 \mathrm{mmol} / \mathrm{l}(\mathrm{O})$. From zero time to $60 \mathrm{~min}$ all incubation media contained $100 \mu \mathrm{mol} / 1$ tolbutamide. Values in the curves are means \pm SEM of results from 6 or 7 separate experiments. By subtracting the $\mathrm{O}_{2}$ uptake rate at $-2 \mathrm{~min}$ from the mean $\mathrm{O}_{2}$ uptake rate between 1.5 and $58 \mathrm{~min}$, the mean respiratory increase was calculated in each separate experiment. The mean respiratory increase of profiles $\square, \boldsymbol{\square}$ or $O$ was significantly higher $(p<0.05, U$-test) than the mean respiratory increase of the corresponding controls $\boldsymbol{\Lambda}, \mathbf{E}$ or $*$ in Figure 4. Further details are the same as described in the legend to Figure 4

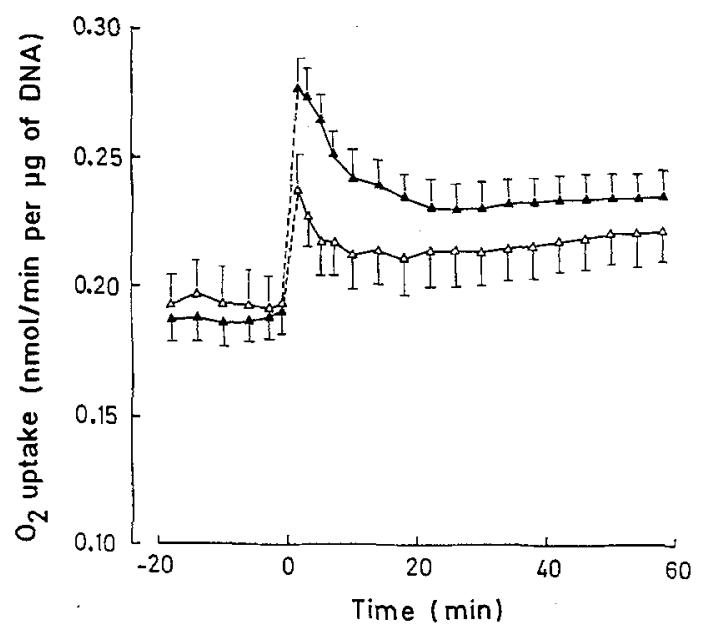

Fig. 6. Effects of tolbutamide concentration on the kinetic of $\mathrm{O}_{2}$ uptake by mouse pancreatic islets. During control $(-20$ to $0 \mathrm{~min})$ and test phase the D-glucose concentration of the incubation medium was $10 \mathrm{mmol} / 1$. From zero time to $60 \mathrm{~min}$ the incubation medium contained $10 \mu \mathrm{mol} / 1(\Delta)$ or $30 \mu \mathrm{mol} / 1$ ( $\Delta$ ) tolbutamide. Values in the curves are means \pm SEM of results from 5 or 6 separate experiments. The mean respiratory increase of both profiles was significantly higher $(p<0.05$, U-test) than the mean respiratory increase of the corresponding control $\boldsymbol{A}$ in Figure 4. Further details are the same as described in the legend to Figure 5 
Table 1. Effects of glucose and tolbutamide on ATP content of pancreatic islets

\begin{tabular}{|c|c|c|c|c|c|}
\hline & $\begin{array}{l}\text { Glucose } \\
\text { concen- } \\
\text { tration } \\
(\mathrm{mmol} / \mathrm{l})\end{array}$ & $\begin{array}{l}\text { Tolbutamide } \\
\text { concentration } \\
(\mu \mathrm{mol} / 1)\end{array}$ & $n$ & $\begin{array}{l}\text { ATP content } \\
(\mathrm{pmol} / \mu \mathrm{g} \\
\text { of DNA) }\end{array}$ & $p$ \\
\hline Control & 5 & 0 & 13 & $220 \pm 21$ & \\
\hline Test & 5 & 100 & 13 & $193 \pm 20$ & $<0.001$ \\
\hline Control $^{\mathrm{a}}$ & 5 & 0 & 17 & $234 \pm 9$ & \\
\hline Test $^{\mathrm{a}}$ & 5 & 100 & 17 & $227 \pm 8$ & NS \\
\hline Control & 10 & 0 & 12 & $239 \pm 10$ & \\
\hline Test & 10 & 10 & 12 & $234 \pm 17$ & NS \\
\hline Control & 10 & 0 & 12 & $250 \pm 16$ & \\
\hline Test & 10 & 30 & 12 & $217 \pm 13$ & $<0.02$ \\
\hline Control & 10 & 0 & 19 & $240 \pm 10$ & \\
\hline Test & 10 & 100 & 19 & $218 \pm 8$ & $<0.005$ \\
\hline Control $^{\mathrm{a}}$ & 10 & 0 & 23 & $236 \pm 6$ & \\
\hline Test $^{\mathrm{a}}$ & 10 & 100 & 23 & $244 \pm 7$ & NS \\
\hline Control & 15 & 0 & 11 & $245 \pm 12$ & \\
\hline Test & 15 & 100 & 11 & $241 \pm 10$ & NS \\
\hline Control & 30 & 0 & 11 & $237 \pm 20$ & \\
\hline Test & 30 & 100 & 11 & $235 \pm 16$ & NS \\
\hline
\end{tabular}

Preincubation and incubation (15 min) of the islets were performed in the presence of the indicated glucose concentrations. Each experimental series consisted of simultaneous incubations in the absence (control) or presence (test) of tolbutamide and in the presence of the same glucose concentrations. Values shown are means \pm SEM for results from 11 to 23 separate experiments. Comparison of control and test was made by Wilcoxon's paired test. a During preincubation and incubation the media contained no calcium and were supplemented with $1 \mathrm{mmol} / 1$ EGTA

lated from the experiments of Figures 1 and 4 and from a DNA content of $20 \mathrm{ng} /$ islet (average islet DNA content of the experimental series).

In the presence of $5,10,15$ or $30 \mathrm{mmol} / 1 \mathrm{D}$-glucose, a high concentration of tolbutamide $(100 \mu \mathrm{mol} / \mathrm{l})$ stimulated $\mathrm{O}_{2}$ uptake in islets by $28,51,26$ or $12 \%$, respectively, within $2 \mathrm{~min}$ (in each series, $p<0.05$ for comparison with the last value before zero time) and afterwards the increase in respiration fell rapidly at 5 or $10 \mathrm{mmol} / 1$ D-glucose and slowly at 15 or $30 \mathrm{mmol} / 1 \mathrm{D}$-glucose (Fig. 5). Low $(10 \mu \mathrm{mol} / \mathrm{l})$ or intermediate $(30 \mu \mathrm{mol} / 1)$ concentrations of tolbutamide, too, enhanced $\mathrm{O}_{2}$ uptake with a maximum at 1.5 to $3 \mathrm{~min}$ in each single experiment (Fig. 6). In the presence of 10 or $15 \mathrm{mmol} / \mathrm{l}$ D-glucose, the tolbutamide-induced increase in $\mathrm{O}_{2}$ uptake was still significant at $58 \mathrm{~min}(p<0.05$ for comparison of series $\square, \boldsymbol{\square}$ or $\boldsymbol{\Delta}$ in Figures 5 and 6 with the corresponding control series $\boldsymbol{\Delta}$ or $\mathbf{\square}$ in Figure 4). In each single experiment of series $\boldsymbol{\bullet}, \square, \mathbf{\square}, \Delta$ or $\boldsymbol{\Delta}$ in Figure 5 and 6 the peak rate was higher than the rate at $10 \mathrm{~min}$. Taking into account the gradual increase in $\mathrm{O}_{2}$ consumption which was observed in control experiments (series $\boldsymbol{\bullet}, \boldsymbol{\Delta}$, and $\mathbf{\square}$ in Figure 4 ) and which may reflect augmentation of synthesizing reactions, the respiratory responses to tolbutamide decreased continuously up to $58 \mathrm{~min}$ in each series in Figures 5 and 6 . The correlation between tolbutamide-induced secretory and respiratory responses is also documented by the ratios of the increase in $\mathrm{O}_{2}$ uptake to the increase in insulin release which are calculated from the experiments of Figures 2-6 and from a DNA content of $20 \mathrm{ng}$ /islet. This ratio ranged between 14 and 22 or between 10 and $14 \mathrm{pmol}$ of $\mathrm{O}_{2} / \mathrm{ng}$ of insulin from 1.5 to $58 \mathrm{~min}$ in the presence of tolbutamide $(100 \mu \mathrm{mol} / \mathrm{l})$ and 10 or $15 \mathrm{mmol} / 1 \mathrm{D}$-glucose respectively. Except for two values, all other ratios ranged below $34 \mathrm{pmol}$ of $\mathrm{O}_{2} / \mathrm{ng}$ of insulin. In the absence of glucose, $500 \mu \mathrm{mol} / 1$ tolbutamide enhanced islet $\mathrm{O}_{2}$ uptake for $12 \mathrm{~min}$. The peak rate was higher by $18 \pm 3 \%$ than the last value before zero time ( $n=5$, respiratory profiles not shown). In contrast to experiments in the presence of extracellular $\mathrm{Ca}^{2+}$ ions [26], stirring caused some disintegration of the islets in $\mathrm{Ca}^{2+}$-free media. In the absence of $\mathrm{Ca}^{2+}$ ions, there was no respiratory response to $100 \mu \mathrm{mol} / 1$ tolbutamide (in the presence of $10 \mathrm{mmol} / 1 \mathrm{D}$-glucose, $n=3$ ).

Since changes in the redox state of pyridine nucleotides probably were not the driving force for the $\mathrm{O}_{2}$ consumption initiated by tolbutamide [12-14] and since previous results were equivocal $[8,12,18-20]$, we examined the effects of tolbutamide on the ATP content of pancreatic islets. In conjunction with 5 or $10 \mathrm{mmol} / 1$ D-glucose, tolbutamide ( 30 or $100 \mu \mathrm{mol} / \mathrm{l})$ lowered islet ATP content significantly (Table $1, p<0.02$ ). These effects were prevented in $\mathrm{Ca}^{2+}$-free media. At higher glucose concentrations there was only a trend of lower ATP levels in the presence of tolbutamide (Table 1). Pcreatine was not found in islets incubated at $10 \mathrm{mmol} / 1$ D-glucose $(n=10$; the detection limit was $15 \mathrm{pmol} / \mu \mathrm{g}$ of DNA). However, substantial creatine kinase activity was measured in mouse islets $\left(0.47 \pm 0.05 \mu \mathrm{mol} \cdot \mathrm{min}^{-1}\right.$. $\mathrm{mg}^{-1}$ of protein, $n=7$ ) ranging between the activities in total pancreas $\left(0.17 \pm 0.03 \mu \mathrm{mol} \cdot \mathrm{min}^{-1} \cdot \mathrm{mg}^{-1}\right.$ of protein, $n=3)$ and brain $\left(3.46 \pm 0.45 \mu \mathrm{mol} \cdot \mathrm{min}^{-1} \cdot \mathrm{mg}^{-1}\right.$ of protein, $n=5$ ).

\section{Discussion}

Our study confirms that an increase in islet $\mathrm{O}_{2}$ consumption starts within a few minutes after elevation of the medium glucose concentration [29, 30]. The initial respiratory responses in the present results were stronger than those observed in the experimental set-up of Hutton and Malaisse [30]. However, the equilibration kinetic in their system was rather slow [30], as indicated by a comparison with another perifusion system of these authors [31]. In the present study glucose-induced initial secretory maxima were never paralleled by $\mathrm{O}_{2}$ uptake peaks. Similar dissociations between insulin release and $\mathrm{O}_{2}$ consumption occurred in mouse islets exposed to endo-2-aminobicyclo [2.2.1]-heptane-2-carboxylic acid ( $\mathrm{BCH})$ [2]. These differences between the secretory and respiratory profiles presumably resulted from the additional work load imposed by fuel-induced synthesizing processes. This view is supported by the 
finding that omission of calcium from the medium had only small effects on $\mathrm{O}_{2}$ uptake in the presence of nutrient secretagogues [30]. In this situation the release but not the biosynthesis of insulin was inhibited [32]. Furthermore, $\mathrm{O}_{2}$ consumption per ng of insulin released from $\min 5$ to $\min 60$ of the test phase was higher after elevation of the glucose concentration than after addition of tolbutamide, which did not stimulate insulin synthesis [10]. For instance, after transitions from $10 \mathrm{mmol} / 1 \mathrm{D}$-glucose to $10 \mathrm{mmol} / 1 \mathrm{D}$-glucose + tolbutamide $(30 \mu \mathrm{mol} / 1)$ or to $15 \mathrm{mmol} / 1 \mathrm{D}$-glucose, the ratios of the increase in $\mathrm{O}_{2}$ uptake to the increase in insulin release were 20 or $48 \mathrm{pmol}$ of $\mathrm{O}_{2} / \mathrm{ng}$ of insulin, respectively, at $\min 30$ (Figs. 1, 2, 4 and 6). This means that a major proportion of the respiratory response to glucose was not caused by stimulation of the secretory process.

The present finding that only a slight increase in islet $\mathrm{O}_{2}$ uptake was initiated by tolbutamide in conjunction with $5 \mathrm{mmol} / 1$ glucose is in accordance with results obtained by the Cartesian diver technique [17]. However, we found increased respiration in response to tolbutamide in the presence of $15 \mathrm{mmol} / 1$ glucose, whereas Stork et al. [17] observed an inhibitory effect of tolbutamide in the presence of $16.7 \mathrm{mmol} / 1$ glucose. This discrepancy may be due to more efficient exchange of gas, ions, glucose and secretory products between medium and islets in the present experiments since smaller islets were used and since the medium was stirred [26, 33]. Moreover, in the Cartesian diver islet respiration was impaired by the absence of medium bicarbonate [30].

The correlation between tolbutamide-induced secretory and respiratory profiles in islets and the failure of sulfonylureas to enhance insulin synthesis [10] favour the view that tolbutamide evoked $\mathrm{O}_{2}$ uptake by the work load imposed by stimulation of insulin secretion. Respiration is driven by the disequilibrium between the overall reduction potential span across the respiratory chain and the cytosolic phosphorylation potential [34]. Tolbutamide apparently does not enhance the availability of reducing equivalents in the B-cell mitochondria [12-14, 21]. Hence, a decrease in the cytosolic phosphorylation potential remains as the driving force for tolbutamide-induced $\mathrm{O}_{2}$ consumption. This decrease was probably reflected in the diminished ATP content of islets incubated at 5 or $10 \mathrm{mmol} / 1$ glucose and at the same tolbutamide concentrations which enhanced islet $\mathrm{O}_{2}$ uptake. This interpretation is supported by inhibition of the secretory, respiratory and ATP-lowering effects of tolbutamide in the absence of extracellular $\mathrm{Ca}^{2+}$ ions. In the presence of high glucose concentrations (15 or $30 \mathrm{mmol} / \mathrm{l}$ ) the expected tolbutamide-induced decrease in islet content of ATP coinciding with the increase in $\mathrm{O}_{2}$ consumption was not detected. This was not due to buffering by the P-creatine/creatine system, because Pcreatine was not found in the mouse islets we used in the present study. It is therefore suggested that the total ATP content of islets does not reflect the ATP concen- tration in cytosolic microenvironments in which major changes in ATP utilization of B cells take place. Substantial microheterogeneity in ATP concentration probably occurs in the cytosol of liver cells [35].

It has been reported previously that sulfonylureas lowered islet content of ATP not only at low (3.3 or $5.6 \mathrm{mmol} / 1 ;[12,19])$ but also at high $(16.7 \mathrm{mmol} / 1 ;[12])$ glucose concentrations. The latter discrepancy to our findings may result from the high tolbutamide concentrations $(0.74 \mathrm{mmol} / 1)$ used, which may have caused additional alterations in B-cell energy metabolism not related to insulin secretion. In the present study tolbutamide in conjunction with $10 \mathrm{mmol} / 1$ glucose was half maximally effective on insulin release at a concentration (around $20 \mu \mathrm{mol} / 1$ ) in the range of therapeutic plasma concentrations of free tolbutamide [36, 37].

It has been suggested that the typical decline of the insulin secretory rate during stimulation with tolbutamide was due to slow inactivation of voltage-dependent calcium channels caused by depolarization [16]. However, this hypothesis does not explain why glucose-induced depolarization is accompanied by biphasic insulin release. It is therefore conceivable that the typical decline of the secretory response to tolbutamide reflects decrease in the ATP concentration in the vicinity of the ATP-regulated $\mathrm{K}^{+}$channel. Yet, it is premature to attribute the insulin releasing effects of tolbutamide and glucose solely to a blockade of this $\mathrm{K}^{+}$channel. The $\mathrm{P}$ creatine content of islets in vivo [38] and the creatine kinase activity in islets indicate that islet cells may lose creatine during the isolation procedure and that the Pcreatine/creatine system could buffer the concentration of cytosolic ATP in vivo. Furthermore, a secretory response to tolbutamide was even observed at a maximally effective glucose concentration which is believed to cause permanent depolarization of B cells [39]. This finding means either that not all $\mathrm{B}$ cells are permanently depolarized or that decreasing the membrane potential of B cells is not the sole mechanism by which sulfonylureas elicit insulin release.

Acknowledgements. The excellent assistance of Ms. B.Schröter and Ms. Y. Hartmann is gratefully acknowledged. This work was supported by the Deutsche Forschungsgemeinschaft. Some of the results described here were obtained during medical thesis work by S.S. and K.K.

\section{References}

1. Ashcroft SJH (1980) Glucoreceptor mechanisms and the control of insulin release and biosynthesis. Diabetologia 18: 5-15

2. Panten U, Zielmann S, Langer J, Zünkler B-J, Lenzen S (1984) Regulation of insulin secretion by energy metabolism in pancreatic B-cell mitochondria. Studies with a non-metabolizable leucine analogue. Biochem J 219: 189-196

3. Panten U, Zielmann S, Joost H-G, Lenzen S (1984) Branched chain amino and keto acids - tools for the investigation of fuel recognition mechanism in pancreatic B-cells. In: Adibi SA, Fekl W, Langenbeck U, Schauder P (eds) Branched chain amino and keto acids in health and disease. Karger, Basle, pp 134-146 
4. Lenzen S, Schmidt W, Panten U (1985) Transamination of neutral amino acids and 2-keto acids in pancreatic B-cell mitochondria. $\mathrm{J}$ Biol Chem 260: 12629-12634

5. Cook DL, Hales CN (1984) Intracellular ATP directly blocks $\mathrm{K}^{+}$ channels in pancreatic B-cells. Nature 311:271-273

6. Ashcroft FM, Harrison DE, Ashcroft SJH (1984) Glucose induces closure of single potassium channels in isolated rat pancreatic $\beta$ cells. Nature 312: 446-448

7. Rorsman P, Trube G (1985) Glucose dependent $\mathrm{K}^{+}$-channels in pancreatic $\beta$-cells are regulated by intracellular ATP. Pflügers Arch 405: 305-309

8. Ashcroft SJH, Weerasinghe LCC, Randle PJ (1973) Interrelationship of islet metabolism, adenosine triphosphate content and insulin release. Biochem J 132: 223-231

9. Malaisse WJ, Hutton JC, Kawazu S, Sener A (1978) The stimulussecretion coupling of glucose-induced insulin release. Metabolic effects of menadione in isolated islets. Eur J Biochem 87: 121-130

10. Hellman B, Täljedal I-B (1975) Effects of sulfonylurea derivatives on pancreatic $\beta$-cells. In: Hasselblatt $\mathrm{A}$, von Bruchhausen $\mathrm{F}$ (eds) Handbook of experimental pharmacology, Vol 32, part 2. Springer, Berlin Heidelberg New York, pp 175-194

11. Sturgess NC, Ashford MLJ, Cook DL, Hales CN (1985) The sulphonylurea receptor may be an ATP-sensitive potassium channel. Lancet 2: 474-475

12. Kawazu S, Sener A, Couturier E, Malaisse WJ (1980) Metabolic, cationic and secretory effects of hypoglycemic sulfonylureas in pancreatic islets. Naunyn-Schmiedeberg's Arch Pharmacol 312: 277-283

13. Panten U, Christians J, von Kriegstein E, Poser W, Hasselblatt A (1973) Effects of carbohydrates upon fluorescence of reduced pyridine nucleotides from perifused isolated pancreatic islets. Diabetologia 9: 477-482

14. Ammon HPT (1975) Effect of tolbutamide on aminophylline-, 3,5-AMP-dibutyrate - or glucagon-induced insulin release from pancreatic islets after impairment of pyridine nucleotide metabolism caused by 6 -aminonicotinamide (6-AN). Naunyn-Schmiedeberg's Arch Pharmacol 290: 251-264

15. Curry DL, Bennett LL, Grodsky GM (1968) Dynamics of insulin secretion by the perfused rat pancreas. Endocrinology (Baltimore) $83: 572-584$

16. Henquin J-C (1980) Tolbutamide stimulation and inhibition of insulin release: studies of the underlying ionic mechanisms in isolated rat islets. Diabetologia 18:151-160

17. Stork H, Schmidt FH, Westman S, Hellerström C (1969) Action of some hypoglycaemic sulphonylureas on the oxygen consumption of isolated pancreatic islets of mice. Diabetologia 5:279-283

18. Welsh M (1983) The effects of glibenclamide on rat islet radioactive nucleotide efflux, ATP contents and respiratory rates. Biochem Pharmacol 32: 2903-2908

19. Hellman B, Idahl L-Â, Danielsson Å (1969) Adenosine triphosphate levels of mammalian pancreatic $B$ cells after stimulation with glucose and hypoglycemic sulfonylureas. Diabetes 18: $509-516$

20. Krzanowski JJ, Fertel R, Matschinsky FM (1971) Energy metabolism in pancreatic islets of rats. Studies with tolbutamide and hypoxia. Diabetes 20: $598-606$

21. Gylfe E, Hellman B, Sehlin J, Täljedal I-B (1984) Interaction of sulfonylurea with the pancreatic B-cell. Experientia 40: 1126-1134

22. Panten U, Biermann J, Graen W (1981) Recognition of insulin-releasing fuels by pancreatic B-cells. $\alpha$-Ketoisocaproic acid is an ap- propriate model compound to study the role of B-cell metabolism. Mol Pharmacol 20: 76-82

23. Lernmark $\AA$ (1974) The preparation of, and studies on, free cell suspensions from mouse pancreatic islets. Diabetologia 10 431-438

24. Panten U, Ishida H, Schauder P, Frerichs H, Hasselblatt A (1977) A versatile microperifusion system. Anal Biochem 82: 317-326

25. Joost H-G (1979) Effects of a possible beta-cell membrane label, metahexamide-isothiocyanate, on insulin release. Horm Metab Res 11: 104-106

26. Panten U, Klein $\mathrm{H}$ (1982) $\mathrm{O}_{2}$ consumption by isolated pancreatic islets, as measured in a microincubation system with a Clark-type electrode. Endocrinology (Baltimore) 111: 1595-1600

27. Lust WD, Feussner GK, Barbehenn EK, Passonneau JA (1981) The enzymatic measurement of adenine nucleotides and P-creatine in picomole amounts. Anal Biochem 110: 258-266

28. Peterson GL (1977) A simplification of the protein assay method of Lowry et al. which is more generally applicable. Anal Biochem $83: 346-356$

29. Hellerström C (1966) Oxygen consumption of isolated pancreatic islets of mice studied with the cartesian-diver micro-gasometer. $\mathrm{Bi}$ ochem J $98: 7 \mathrm{c}-9 \mathrm{c}$

30. Hutton JC, Malaisse WJ (1980) Dynamics of $\mathrm{O}_{2}$ consumption in rat pancreatic islets. Diabetologia 18: $395-405$

31. Herchuelz A, Couturier E, Malaisse WJ (1980) Regulation of calcium fluxes in pancreatic islets: glucose-induced calcium-calcium exchange. Am J Physiol 238: E96-E103

32. Permutt MA (1981) Biosynthesis of insulin. In: Cooperstein SJ, Watkins D (eds) The islets of Langerhans. Biochemistry, physiology and pathology. Academic Press, New York London Toronto, pp 75-95

33. Perez-Armendariz E, Atwater I, Rojas E (1985) Glucose induced oscillatory changes in extracellular ionized potassium concentration in mouse islets of Langerhans. Biophys J 48: 741-749

34. Hansford RG (1980) Control of mitochondrial substrate oxidation. Curr Top Bioenerg 10: 217-278

35. Aw TY, Jones DP (1985) ATP concentration gradients in cytosol of liver cells during hypoxia. Am J Physiol 249: C 385-C 392

36. Jackson JE, Bressler R (1981) Clinical pharmacology of sulfonylurea hypoglycaemic agents: part 1 . Drugs 22:211-245

37. Zini R, d'Athis P, Hoareau A, Tillement JP (1976) Binding of four sulphonamides to human albumin. Europ J Clin Pharmacol 10: $139-145$

38. Matschinsky FM (1972) Enzymes, metabolites, and cofactors involved in intermediary metabolism of islets of Langerhans. In: Steiner DF, Freinkel N (eds) Handbook of physiology, Section 7 Vol 1. American Physiological Society, Washington DC, pp 199-214

39. Henquin JC, Meissner HP (1984) Significance of ionic fluxes and changes in membrane potential for stimulus-secretion coupling in pancreatic B-cells. Experientia 40: 1043-1052

Received: 27 January 1986

and in revised form: 14 July 1986

Dr. U. Panten

Institute of Pharmacology and Toxicology

University of Göttingen

Robert-Koch-Straße 40

D-3400 Göttingen

FRG 